institutions, reproduced features of the research object on the example of the developed pedagogical model and established interrelations between the system elements of the process of informative competence formation. The basis of the article is to highlight the opinions of the significant number.

During the analysis of scientific and pedagogical literature the components of the pedagogical model of the formation of future professional training teachers' informative competence were defined and pedagogical conditions and blocks of pedagogical model were singled out. In view of theoretical analysis it is possible to say that pedagogical model has such interconnected blocks: Target - Contains goals, tasks, approaches (systemic, synergistic, competence, active, interdisciplinary, acmeological) and principles (the base of didactic, specific); Semantic -includes the components of informative competence (motivational-axiological, cognitive, active-professional, appraisal-reflexive), content, stages, forms and methods of training; effective-appraisal - includes criteria, indicators and levels that facilitate obtaining of a specific result, i.e. the formation of future professional training teachers' informative competence during the in higher education institutions.

On the basis of the analysis of scientific and pedagogical literature, a pedagogical model was developed, which is quite efficient and aimed at the formation of future professional training teachers' informative competence. It is also an impetus to the development of educational and methodological support and special courses proposed the model of the formation of future professional training teachers' informative competence during the in higher education institutions.

Key words: competence, informative competence, component, model, pedagogical model, education, criteria, higher education, educator of professional training.

Дата надходження статті: 20.01.2020 p. Рецензент: доктор педагогічних наук, доцент Грудинін Б. О.

УДК 378.371.134:37.025.8

DOI https://doi.org/10.37915/pa.vi45.87

Бурчак C. О.,

orcid.org/0000-0002-1641-3251

\title{
ХАРАКТЕРИСТИКА МОДЕДІ СИСТЕМИ РОЗВИТКУ ТВОРЧОСТІ МАЙБУТНІХ УЧИТЕЛІВ МАТЕМАТИКИ
}

У статті схарактеризовано модель систели розвитку творчості майбутніх учителів математики в процесі фахової підготовки в педагогічному університеті. Висвітлено аналіз працьв сучасних науковців з питань проєктування, моделювання, моделей різноманітних педагогічних процесів. Крім того, представлено детальний опис їі структурних компонентних складників (соціальне замовлення, мета $i$ завдання, методологічний, теоретичний, практичний, результативно-коригувальний компоненти), а також указана умова достатньої узагальненості досліджуваних змістових і структурно-процесуальних ї̈ компонентів, завдяки виконанню якої вона може бути апробованою та реалізованою в реальному освітньому проиесі педагогічних закладів вищої освіти.

Подано основні етапи процесу моделювання системи (осмислення й визначення функцій модельованого об'єкту; побудова максимально функціональної системи наскрізних компонентів структури досліджуваного об'єкту; установлення функціонального, логічного, технологічного, семантичного та інших видів взаємозв'язків між компонентами моделі; вивчення динахіки досліджуваного об'єкту, закономірностей функціонування системи; накопичення відомостей про об'єкт дослідження за допомогою теоретичних та емпіричних методів дослідження).

*(C) Бурчак С. O.

os 
Розглянуто поняття творчості майбутніх учителів математики, яку в межах нашого дослідження розуміємо, як сукупність рівноцінних самостійних компонентних складників (мотиваційного, когнітивного, діяльнісного, рефлексивного), що сприяють активній творчій діяльності здобувачів вищої освіти, яка спрямована на розв'язання освітніх завдань, а розроблена модель розвитку творчості майбутніх учителів математики в процесі фахової підготовки, насамперед, відображае результати теоретичного пошуку (обьрунтовані завдання, методологічні підходи, принцุипи, фактори, педагогічні умови, етапи, структурні компоненти, критерії, показники тощо) щодо проєктування відповідної системи.

Ключові слова: моделювання, модель, система, творчість, розвиток творчості майбутніх педагогів, здобувачі вищої освіти, педагогічний університет.

Постановка проблеми. Аналіз професіограми сучасного вчителя показує, що він має розпоряджатися й володіти набором спеціальних здібностей, що сприяють розвитку умінь розв'язувати низку сучасних, найголовніших професійних завдань, які ставить перед ним школа і суспільство: досліджувати, проєктувати, створювати освітні ситуації тощо. В умовах реформування системи освіти України, де кдючовою реформою виступає Нова українська школа, головною метою якої є створення школи, уякій якісно й комфортно навчатимуться учні, де вони не лише отримуватимуть теоретичні знання, а й уміння використовувати їх у професійній діяльності і в повсякденності, упровадження в заклади освіти новітніх технологій сучасні учителі, у тому числі й математики, мають мати гдибокі метододогічні знання, вододіти рядом професійних умінь та здатностей розв'язувати типові і нетипові педагогічні завдання і ситуації.

Саме тому науково-педагогічні працівники педагогічних закладів вищої освіти повинні комплексно, систематично й на високому науково-методичному рівні готувати здобувачів вищої освіти до виконання творчої педагогічної діядьності, а, отже, й розвивати творчість майбутніх учителів математики в процесі їхньої фахової підготовки, чому й сприятиме спроєктована система розвитку творчості майбутніх учителів математики.

Аналіз досліджень. Поняттям «проєктування» як методом наукової та теоретичної діяльності займалися ряд вітчизняних науковців (Н. Алексеєв, А. Ващенко, Ю. Громико, Є. Ісаєв, О. Сфімов, О. Новіков, Д. Новіков, В. Слободчиков, М. Фіцула, Г. Щедровицький та ін.).

Переважна більшість учених схиляеться до думки, що проєктування в науковопедагогічних дослідженнях найчастіше здійснюеться за допомогою методу моделювання, адже, як стверджують Г. Матушинський та А. Фролов, «...воно надає можливості об'єднувати в науково-педагогічних дослідженнях емпіричне та теоретичне, поєднувати експеримент 3 побудовою логічних конструкцій та наукових абстракцій у процесі вивчення педагогічних об' єктів тощо» [5, с. 187].

Отже, резудьтатом процесу проєктування є модель. С. Гончаренко на сторінках власних праць говорить, що процес моделювання полягає в «...установленні подібності явищ (аналогій), адекватності одного об'єкта іншому в певних відношеннях, і на цій основі перетворення простішого за структурою і змістом об'єкта в модель складнішого (оригінал)». Поняття «модель», у його розумінні - це «...штучна система елементів, яка з певною точністю відображає деякі властивості, зв'язки досліджуваного об'єкта». Автор переконаний, що «...потреба в моделюванні виникає тоді, коли дослідження самого об'єкта неможливе, є занадто складним і дорогим, вимагає надто тривалого часу тощо» $[2$, с. 134].

Метою статті є характеристика моделі системи розвитку творчості майбутніх учителів математики в процесі фахової підготовки.

Виклад основного матеріалу. Одним із пріоритетних завдань нашого дослідження є проєктування системи розвитку творчості майбутніх учителів

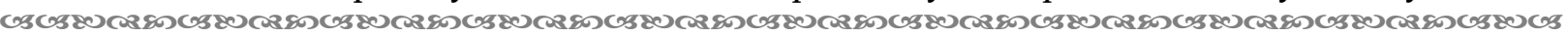


математики в процесі фахової підготовки, а також розроблення методичного забезпечення для ії практичної реалізації. Звичайно, проєктування системи вимагає, насамперед, побудови відповідної моделі. Ддя досягнення мети використовуємо метод моделювання, оскільки він є чи не найдієвішим у сучасних науково-педагогічних дослідженнях [4].

Певною особливістю моделі системи розвитку творчості майбутніх учителів математики $є$ те, що основою iї побудови $є$ сукупність декількох метододогічних підходів: системного, діядьнісного, особистісно-орієнтованого, контекстного, інформаційного, інтеграційного, середовищного, діалогічного тощо. Під час побудови окресленої моделі враховано основні особливості указаних підходів: відповідність основним положенням Стратегії реформування середньої освіти до 2029 р. «Нова українська школа»; орієнтування на кінцеву мету діяльності; наявність постійного зворотного зв'язку вчителя 3 учнями і батьками; оптимальне співвідношення теоретичної та практичної складових освітнього процесу з математики на основі їхньої функціональної інтеграції тощо.

Погоджуючись 3 думкою Б. Грудиніна, констатуємо той факт, що зміна певних умов (зниження рівня абстрагування на етапі побудови моделі тощо), сприятиме зростанню кількості змістових і структурно-процесуальних компонентів моделі, що призведе до суттєвого ускладнення іï інтерпретації та ускладнить (навіть унеможливить) розроблення технології іiі реалізації. Системоутворювальним чинником навчання за таких умов буде сукупність способів керівництва, методів і принципів навчання [3].

Розроблена модель повинна бути апробованою та реалізованою в реальному освітньому процесі педагогічних закладів вищої освіти лише за умови достатньої узагальненості досліджуваних змістових і структурно-процесуальних ії компонентів.

Процес їі моделювання відбувався в декілька етапів: на першому етапі відбувадося саме осмислення проєктування моделі, визначалися функції модельованого об'єкта (системи розвитку творчості майбутніх учителів математики), визначалося значення, місце, можливості їі реалізації в освітньому процесі педагогічного закладу вищої освіти; на другому emani будувалася максимально функціональна система наскрізних компонентів структури досліджуваного об'єкту, визначалися критерії функціональності моделі, проводилися заходи контролю для перевірки максимальності вибору наскрізних компонентів структурного складу досліджуваного об'єкта та функціональних можливостей кожного окресленого складника; на третьому етапі встановдювався функціональний, иогічний, технологічний, семантичний та інші види взаємозв'язків між компонентами моделі; на четвертому етапі вивчалася динаміка досліджуваного об'єкта (закономірності функціювання системи;@ накопичення відомостей; формулювання завдань; визначення динаміки зміни, самоорганізації або розвитку системи; установлення зв'язків та аналіз умов функціювання модельованого об'єкта).

Авторська модель системи розвитку творчості майбутніх учителів математики в процесі фахової підготовки представлена на рис. 1.

Ця модель містить такі компоненти: соціальне замовлення; ц̧ілі $i$ завдання; методологічний; теоретичний; практичний; результативно-коригувальний.

Зауважимо, що вказані компоненти є взаємопов'язаними між собою, кожен 3 них має певний вплив на інший шляхом розв' язання визначених для нього завдань. На нашу думку, така організація функціювання моделі дозводить досягти бажаного результату розвитку творчості майбутніх учителів математики. Входження України в світовий освітній простір вимагає привести існуючі вітчизняні освітні стандарти у відповідність до норм усього світового співтовариства. Фундаментальними ідеями таких перетворень повинні бути реальні знання про потенційні можливості школярів певної вікової категорії, прогнозування моделей і потреб розвитку кожного учня, на чому й грунтується використання сучасних освітніх технологій.

us 


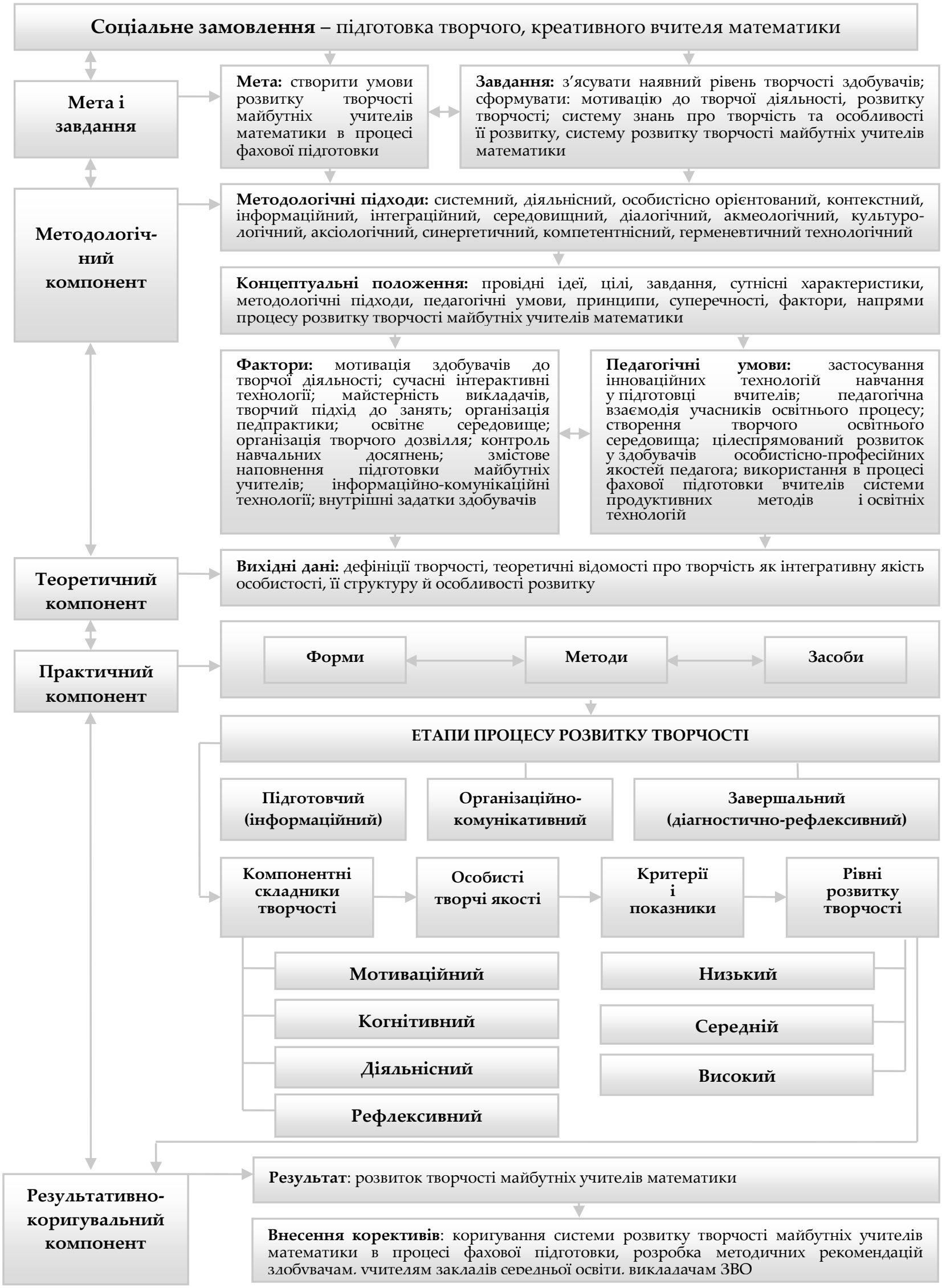

Рис. 1. Модель системи розвитку творчості майбутніх учителів математики в процесі фахової підготовки 
Це стає можливим за умови надання пріоритетної уваги змісту освіти, методикам, що формують ціннісні орієнтації учнів, їхній світогляд, уміння щодо самоосвіти, критичного мислення, використання комп'ютерних технологій, здатності до самореалізації школярів у всіх видах творчої діяльності.

Усе це підтверджуе правильність соціального замовлення (підготовка творчого, креативного вчителя), яке і є першим компонентом авторської моделі. Адже саме такого вчителя сьогодні вимагають умови Нової української школи, інклюзивної освіти, STЕМосвіти тощо.

У компоненті «Мета $\boldsymbol{i}$ завдання» відображено мету реалізації вказаної моделі: створити умови розвитку творчості майбутніх учителів математики в процесі фахової підготовки. Крім того, цей компонент конкретизуе завдання: з'ясувати наявний рівень творчості здобувачів вищої освіти, що й стане показником їхньої готовності до роботи над розвитком власної творчості в умовах педагогічного університету; сформувати в майбутніх учителів математики мотивацію до творчої діяльності, бажання розвивати власну творчість, сприймати ії як особисту цінність; сформувати в майбутніх педагогів систему знань про творчість та особливості іï розвитку, систему розвитку творчості майбутніх учителів математики.

Зауважимо, що наявний у здобувачів вищої освіти рівень творчості визначаємо шляхом аналізу іï компонентних складників (мотиваційного, когнітивного, діядьнісного, рефлексивного), які й складають основу можливостей виконувати ними окреслену діядьність. Розвиток мотиваційного складника щодо розвитку творчості майбутнього педагога, як передбачено представленою моделлю, відбувається впродовж усього періоду навчання здобувача в університеті й вимагае від викладачів застосування різноманітних методів, засобів і прийомів актуалізації в майбутнього вчителя математики мотивів щодо розвитку власної творчості, сприйняття іiі за особистісну цінність.

Крім того, модель передбачає формування в майбутніх учителів системи знань 3 математики, методики навчання математики, педагогіки, психології, знань 3 теорії творчості, розвиток творчих особистісних якостей тощо (розвиток когнітивного компонентного складника) впродовж усього періоду реалізації запропонованої моделі розвитку творчості майбутніх учителів математики в процесі фахової підготовки. Паралельно 3 виконанням окресленої діяльності майбутні педагоги овододівають уміннями індивідуалізувати зміст творчої діяльності (розвиток діяльнісного компоненту), розвивають рефлексивні й комунікативні вміння (розвиток рефлексивного компоненту) тощо.

Методологічний компонент вміщуе метододогічні підходи, на яких грунтуеться системне дослідження проблеми розвитку творчості майбутніх учителів математики в процесі фахової підготовки. Крім того, цей компонент моделі відображае концептуальні положення розвитку творчості майбутніх учителів математики, які містять:

провідні ідеї (визнання особистості майбутнього вчителя математики, який виступає суб'єктом освітнього процесу в педагогічному університеті, його цінності, унікальності й індивідуальності; ідеї розвитку творчої особистості вчителя з урахуванням потреб сучасної шкоди, суспільства, а також, ураховуючи інтереси й потреби самого здобувача вищої освіти; модернізація освітнього процесу в педагогічному університеті має спрямовуватися на удосконалення усіх його складових);

цілі розвитку творчості майбутніх учителів математики (на основі визначених наукових і методичних основ професійної підготовки визначити теоретичні й методичні засади процесу розвитку творчості майбутніх учителів математики під час фахової підготовки як системи, яка сприяє підвищенню рівня та якості підготовки указаних педагогічних працівників до творчого виконання своїх професійних обов'язків); 
завдання розвитку творчості майбутніх учителів (схарактеризувати й обгрунтувати основні метододогічні підходи й принципи розвитку творчості майбутніх педагогічних працівників; з'ясувати фактори та обгрунтувати педагогічні умови розвитку творчості здобувачів вищої педагогічної освіти; визначити основні напрями системного розвитку творчості майбутніх педагогів-математиків і виконати проєктування указаного процесу як концептуальну модель);

методологічні підходи (системний, діяльнісний, особистісно-орієнтований, контекстний, інформаційний, інтеграційний, середовищний, діалогічний, акмеологічний, культурологічний, аксіологічний, синергетичний, компетентнісний, герменевтичний технологічний);

принципи розвитку творчості майбутніх учителів (взаємозумовленості освіти і творчого розвитку особистості, самоорганізації, узгодження розвитку здобувачів з власними тенденціями розвитку, креативності, діагностики, оптимальності, варіантності, доповнення, фасилітації, розвивального і виховувального навчання, професійної мобільності, інформатизації (комп'ютеризації) навчання, професійної спрямованості навчання, модульності навчання);

фактори розвитку творчості майбутніх учителів (мотивація здобувачів до творчої педагогічної діяльності; сучасні інтерактивні технології навчання; майстерність викладачів, творчий підхід до проведення аудиторних і позанавчадьних занять; організація педагогічної практики здобувачів вищої освіти; освітне середовище в педагогічному університеті; організація творчого дозвілля і позанавчальної діяльності майбутніх учителів; контроль навчальних досягнень здобувачів вищої освіти; змістове наповнення підготовки майбутніх учителів математики; інформаційно-комунікаційні технодогії і мождивості їх використання; внутрішні задатки здобувачів до творчої діяльності);

педагогічні умови розвитку творчості майбутніх учителів (застосування інноваційних технодогій навчання у фаховій підготовці майбутніх учителів математики; педагогічна взаємодія учасників освітнього процесу з орієнтуванням на особистісний розвиток здобувачів; створення творчого освітнього середовища; цілеспрямований розвиток уздобувачів вищої освіти особистіснопрофесійних якостей майбутнього педагога; використання в процесі фахової підготовки вчителів системи продуктивних методів і освітніх технологій);

напрями процесу розвитку творчості майбутніх учителів математики (інтерактивні лекції, практичні, лабораторні заняття і семінари; самостійна й науково-дослідницька робота майбутніх педагогів; практикоорієнтована підготовка; позааудиторна робота і форми контролю навчальних досягнень здобувачів; інформатизація освітнього процесу педагогічного закладу вищої освіти; педагогічна інтеграція тощо).

Теоретичний компонент цієї моделі вміщуе систему вихідних параметрів, дефініцій творчості, що складають основу розуміння сутності та структури творчості майбутніх учителів математики, а також моделювання системи розвитку творчості майбутніх педагогів. Основою цього компонента виступають теоретичні відомості про творчість як інтегративну якість особистості, їі структуру й особливості розвитку.

У межах нашого дослідження творчість майбутніх учителів математики розуміємо як сукупність рівноцінних самостійних компонентних складників (мотиваційного, когнітивного, діяльнісного, рефлексивного), що сприяють активній творчій діяльності здобувачів вищої освіти, яка спрямована на розв'язання освітніх завдань. Структура творчості майбутніх педагогів представлена в таблиці 1.

Практичний компонент модеді розвитку творчості майбутніх педагогів у межах нашого дослідження реалізуеться через використання відповідних форм (індивідуальні й групові), методи (творчі, креативні, словесні, практичні, інтерактивні, дослідницькі проєкти, вебквести тощо), засоби (технічні й дидактичні засоби навчання, інтернет- 
ресурси, прикладне програмне забезпечення, спеціальне програмне забезпечення тощо). Окреслений компонент представлений трьома етапами.

Таблиия 1

\section{Структура творчості майбутніх педагогів}

\begin{tabular}{|c|c|c|}
\hline \multirow{5}{*}{ 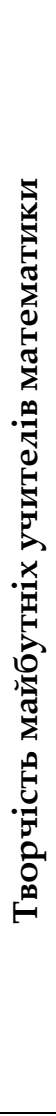 } & $\begin{array}{c}\text { Компонентний } \\
\text { скдадник } \\
\text { творчості } \\
\end{array}$ & Показники \\
\hline & Мотиваційний & $\begin{array}{l}\text { - наявність задатків до творчої діяльності (розвиток уваги, пам'яті, } \\
\text { уяви, прояв активності, ініціативності тощо); } \\
\text { - усвідомлення значення розвитку творчості; } \\
\text { - наявність інтересу до розвитку творчості; } \\
\text { - прийняття творчості як життєвої цінності. }\end{array}$ \\
\hline & Когнітивний & $\begin{array}{l}\text { - повнота, глибина, системність і якість засвоєних майбутніми } \\
\text { учителями математики знань із комплексу дисциплін (педагогіки, } \\
\text { психології, математики, методики навчання математики); } \\
\text { - уявлення про зміст, форми самостійної роботи; } \\
\text { - уміння планувати свої дії, робити висновки та загальні висновки } \\
\text { щодо професійних питань, у тому числі й розвитку творчості учнів }\end{array}$ \\
\hline & Діяльнісний & $\begin{array}{l}\text { - овододіння майбутніми учителями математики системою міцних, } \\
\text { усвідомдених практичних дій та вмінь; } \\
\text { - здатність генерувати ідеї пошуку розв'язків завдань, створювати } \\
\text { незвичайні способи розв'язування задач; } \\
\text { - здатність відрізняти індивідів, які виявдяють гнучкість під час } \\
\text { розв'язування задач; } \\
\text { - здатність швидко перемикатись з однієї ідеї на іншу, готовність } \\
\text { працювати в новому контексті; } \\
\text { - уміння працювати із джерелами інформації, продуктивно } \\
\text { використовувати НІт }\end{array}$ \\
\hline & Рефлексивний & $\begin{array}{l}\text { - здатність до самостійної діяльності в процесі розвитку творчості; } \\
\text { - здатність продуктивно використовувати власний час; } \\
\text { - здатність до самоаналізу власної діяльності; } \\
\text { - здатність вносити корективи в процес розвитку творчості }\end{array}$ \\
\hline
\end{tabular}

На підготовчому (інформаційному) етапі проводилися такі дії: обговорення 3 колективом проблеми дослідження, особливостей розвитку творчості майбутніх учителів математики 3 використанням окресленої моделі; налагодження зв'язків з викладачами відповідних кафедр; уточнення завдань і плану спільної діяльності викладачів і майбутніх учителів, розроблення комплексу; обговорення умов реалізації моделі системи розвитку творчості майбутніх учителів; визначення рівня розвитку творчості майбутніх учителів математики (пілотажне дослідження) та обробка отриманих даних.

Організаційно-комунікативний етап реалізації моделі характерний упровадженням iï в реальний процес педагогічних закладів вищої освіти, використовуючи розроблене авторське навчально-методичне забезпечення, обов' язковою умовою чого виступає тісна співпраця викладачів університетів і здобувачів.

На завершальному (діагностично-рефлексивному) етапі відбувалася кінцеве визначення рівнів розвитку творчості майбутніх учителів математики в процесі їхньої фахової підготовки. Під час діагностики рівнів розвитку творчості майбутніх педагогів на обох етапах (підготовчому (інформаційному) i завершальному (діагностичнорефлексивному)) використовувадися одні й ті ж показники й критерії творчості майбутніх педагогів.

Результативно-коригувальний компонент уміщуе очікувані результати впровадження моделі системи розвитку творчості майбутніх учителів математики в реальний освітній процес педагогічних закладів вищої освіти, якісний та кількісний 
аналіз отриманих результатів, динаміки розвитку творчості майбутніх педагогів, формулювання висновків. Важливо повідомити результати впровадження в освітній процес моделі не лише викладачам університету, а й здобувачам. На нашу думку, це стимулюватиме майбутніх педагогів до самоосвіти, самопізнання, саморозвитку творчих умінь, схильності до самовдосконалення. Спираючись на отримані результати і зроблені висновки, на окресленому етапі дослідження треба внести деякі корективи в модель розвитку творчості майбутніх учителів математики, розробити методичні рекомендації здобувачам вищої освіти, викладачам закладів вищої освіти, учителям закладів середньої освіти та ін.. $з$ питань розвитку творчості педагогів.

Висновки. Розроблена модель розвитку творчості майбутніх учителів математики в процесі фахової підготовки, насамперед, відображає результати теоретичного пошуку (обгрунтовані завдання, методологічні підходи, принципи, фактори, педагогічні умови, етапи, структурні компоненти, критерії, показники тощо) щодо проєктування відповідної системи. Перспективу подальших розвідок убачаємо в упровадженні моделі системи розвитку творчості майбутніх учителів математики в процесі фахової підготовки в реальний освітній процес педагогічних закладів вищої освіти.

\section{Список використаних джерел:}

1. Бурчак С. Підготовка майбутніх учителів початкових класів до розвитку творчого мислення учнів у процесі навчання математики : методичний посібник Суми : РВВ СОIППО, 2010. $116 \mathrm{c}$.

2. Гончаренко С. У. Педагогічні дослідження. Методологічні поради молодим науковцям. Київ-Вінниця : ТОВ фірма «Плавер», 2010. 308 с.

3. Грудинін Б. О. Теоретико-методичні засади розвитку дослідницької компетентності учнів діцею у процесі навчання фізики : дис. ... д-ра пед. наук: 13.00 .02 / Національний педагогічний університет ім. М. П. Драгомакова. Київ, 2019. 547 с.

4. Давидова Г. А. Творчество и диалектика. Москва : Наука, 1976. 175 с.

5. Матушинский Г. У., Фролов А. Г. Проектирование моделей подготовки к профессиональной деятельности преподавателей высшей школы. Educational Technology and Society. 2000. № 3 (4). C. $183-192$.

\section{References:}

1. Burchak, S. (2010). Pidhotovka maibutnikh uchyteliv pochatkovykh klasiv do rozvytku toorchoho myslennia uchniv $u$ protsesi navchannia matematyky [Preparing future primary school teachers to develop students' creative thinking in mathematics learning]. Sumy: RVV SOIPPO [in Ukrainian].

2. Goncharenko, S. U. (2010). Pedahohichni doslidzhennia. Metodolohichni porady molodym naukovtsiam [Pedagogical research. Methodological tips for young scientists]. Kyiv-Vinniczya: "Plaver" [in Ukrainian].

3. Hrudynin, B. O. (2019). Teoretyko-metodychni zasady rozvytku doslidnytskoi kompetentnosti uchniv litseiu u protsesi navchannia fizyky [Theoretical and methodological foundations of the development of research competence of Lyceum students in the process of teaching physics]. (Doctor's thesis). National Pedagogical Dragomanov University. Kyiv [in Ukrainian].

4. Davidova, G. A. (1976). Tvorchestvo i dialektika [Creativity and dialectics]. Moscow: Nauka [in Russian].

5. Matushinskij, G. U., \& Frolov, A. G. (2000). Proektirovanie modelej podgotovki k professional'noj deyatel'nosti prepodavatelej vysshej shkoly [Design of models of preparation for professional activity of teachers of higher education]. Educational Technology and Sosiety, 3 (4), 183-192 [in Russian].

Burchak S. O., orcid.org/ 0000-0002-1641-3251

\section{CHARACTERISTICS OF THE MODELS OF DEVELOPMENT OF CREATIVITY OF FUTURE MATH TEACHERS}

The article describes a model of the system of development of creativity of future mathematics teachers in the process of professional training at a pedagogical university. The analysis of the works 
of modern scientists on the issues of designing, modeling, models of various pedagogical processes is covered. In addition, a detailed description of its structural component components (social order, purpose and objectives, methodological, theoretical, practical, effective and corrective components) is presented, as well as a condition of sufficient generalization of the studied substantive and structural and procedural components by which it can be fulfilled tested and implemented in the real educational process of pedagogical institutions of higher education.

The basic stages of the process of system modeling (understanding and defining the functions of the simulated object; construction of the maximum functional system of the through components of the structure of the investigated object; establishing functional, logical, technological, semantic and other types of relationships between the components of the model; study the dynamics of the studied object, the accumulation of information about the object of study using theoretical and empirical methods of research).

The concept of creativity of future teachers of mathematics is considered, which in the framework of our research is understood as a set of equal independent component components (motivational, cognitive, activity, reflexive), contributing to the active creative activity of the students of higher education, which is aimed at solving educational model, developed development of creativity of future mathematics teachers in the process of professional training, primarily reflects the results of theoretical search (substantiated tasks, methodological odes, principles, factors, pedagogical conditions, stages, structural components, criteria, indicators etc.) for Marine appropriate system.

Key words: modeling, model, system, creativity, development of creativity of future educators, applicants for higher education, pedagogical university.

\section{ВИЗНАЧЕННЯ СУТНОСТІ ПОНЯТТЯ «ПІСЛЯДИПЛОМНА ОСВІТА КЕРІВНИКІВ ЗАКЛАДІВ ЗАГАЯЬНОЇ СЕРЕДНЬОЇ ОСВІТИ УКРАЇНИ»}

У статті розглянуто зміст понять «освіта», «освіта дорослих», «післядипломна освіта», «керівник», «заклад освіти»; здійснено огляд ключових концепцій вітчизняних, законодавчих визначень стосовно трактувань та структури зазначених понять. На основі логіко-структурного аналізу дослідження встановлено загальні явища та особливості, що стосуються післядипломної освіти керівних педагогічних кадрів. Виявлено, що післядипломна освіта керівників закладів освіти має системний характер та спрямована на вдосконалення вже набутого педагогічного та управлінського досвіду впродовж життя тапедагогічної діяльності, які $е$ свідченням становлення керівника закладу освіти. Управлінські компетентності керівників закладів освіти, що удосконалюються та формуються в процесі післядипломної освіти, залежать не тільки від попередньо набутих знань, умінь та навичок, а також від наповнення освітнього середовища навчальними дисциплінами з високим рівнем науковості. Проаналізовано базові категорії поняття, закцентовано на близькості сутності понять «освіта» та «післядипломна освіта»; з'ясовано сутність поняття «керівник» та виокремлено його особливості в контексті поняття «керівник закладу освіти»; опрацьвовано праці вітчизняних науковиів В. Андрущенко, О. Аніщенко, І. Жорової, А. Кисіль, Є. Коренева, В. Кременя, А. Аук'янової, І. Передборської, 